\title{
Branchiogenic deafness syndrome
}

INSERM

\section{Source}

INSERM. (1999). Orphanet: an online rare disease and orphan drug data base.

Branchiogenic deafness syndrome. ORPHA:50815

Branchiogenic deafness syndrome is a multiple congenital anomalies syndrome, described in one family to date, characterized by branchial cysts or fistulae; ear malformations; congenital hearing loss (conductive, sensorineural, and mixed); internal auditory canal hypoplasia; strabismus; trismus; abnormal fifth fingers; vitiliginous lesions, short stature; and mild learning disability. Renal and uretral abnormalities are absent. 